\section{How to Improve Sharia Accountability for Sovereign Sukuk in Indonesia}

\author{
Erny Arianty \\ Politeknik Keuangan Negara STAN, Indonesia \\ ariantyerny@gmail.com
}

How to

Improve Sharia

Accountability

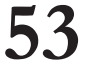

\begin{abstract}
The study aims to analyze the factor that has the highest level of importance in realizing sharia accountability. The analysis of this research is conducted by applying Analytical Hierarchy Process (AHP) approach with a hierarchy structure consisting of the first level, namely objectives, sharia accountability for Sovereign Sukuk/ Sovereign Sharia Securities (SBSN), then the second level is shariah accountability parameters, consist of structural contract (akad) SBSN, the use of SBSN funds by maqashid sharia, and SBSN accounting and financial reporting. Each criterion is determined by sub-criteria, which are the third level. The last level is the supporting factors for the realization of sharia accountability for SBSN. The results showed that human resources competency factor had the highest importance level in realizing the sharia accountability for the use of the contract structure (aqad) SBSN parameter, the supervisory function factor had the highest importance level for the parameters of using SBSN funds following the shariahmaqashid, and the decision making authority factor had the highest importance level for the parameters of accounting and financial reporting. As for the results of the level of importance of the parameters, the parameter of the use of the contract structure has the highest importance level among other parameters.
\end{abstract}

Keywords: Sharia accountability, Sovereign sukuk, Analytical hierarchy process.

\title{
INTRODUCTION
}

Sovereign Sharia Securities (SBSN) or known as Sovereign Sukuk, is one of the sources of State Budget (APBN) financing. Sovereign Sukuk is different from other sources of financing because it is based on sharia principles so that this Sovereign Sukuk also has a role as a catalyst for the development of the Islamic financial industry both domestically and internationally (Alfirman, 2018). Sovereign Sukuk had a strategic position in the framework of developing sharia financial markets because by issuing SBSN, the government provides sharia-based instruments in the market so that shariabased investors (retail/individuals or institutions) have access to these sharia-based instruments. The Sovereign Sukuk also directly contributed to

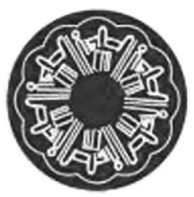

IQTISHADIA Vol. $13(1) 2020$ PP. 53 - 76 P-ISSN: 1979 - 0724 E-ISSN: $2502-3993$ DOI : 10.21043/iqtishadia.v13i1.6618 
IQTISHADIA

13,1

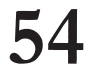

accelerating national development in the field of APBN infrastructure with several projects financed from APBN funds, such as the construction of the railroad double-track Cirebon-Kroya, the construction of hajj halls in several provinces, education infrastructure, road and bridge construction in several provinces, as well as the construction of railroad lines in Jabotabek (Public Finance Training Center, BPPK, 2017).

By looking at the characteristics of sharia-based SBSN and the role of SBSN in developing sharia financial markets, the government needs to maintain sharia accountability. The accountability is one of factors that support the issuance of sukuk (Labolo and Achyari, 2018). The sharia accountability is the process of actualizing the implementation of sharia values that gives grace to humans and nature as a form of servitude to God, who is all-coming (Triyuwono, 2010). It aims to gain high trust from the public. As we know, a majority Muslim community requires financial instruments and the existence of a capital market based on sharia principles that are free from interest, maysir, and gharar (Sivalingam, 2013). Sharia accountability must be realized with the aim the people have the confidence that their investments are safe base sharia and will increase investor interest in investing in SBSN. Islamic accountability becomes essential because the impact of not materializing Islamic accountability can lead to a lack of trust from investors and customers, which will ultimately have an impact on the withdrawal of funds invested (Chapra \& Ahmed, 2002).

The fact that non-compliance with sharia accountability had occurred in 2007 was one of the causes of the collapse of the Sukuk market in 2008, together with the 2008 global financial crisis (Jazil \& Nursyamsiah, 2016). It is due to the use of asset-based Sukuk that is still on used as the basis for Sukuk issuance. Compliance with sharia principles is only fulfilled from the form side, while from the substance side, it has not been fulfilled. Abdullah also said that Sukuk issued based on asset-based Sukuk were still questioned how far the level of compliance with sharia (Abdullah, 2012). It is due to not fulfilling the two elements of compliance with sharia provisions, namely in the form/document and substance. Ahmed and Islam (2019) also studied about legitimacy of sukuk structure that result to increase public awareness, the two elements of sharia compliance must be fulfilled, namely in the form/ document and substance. The use of assets based Sukuk-also applied in establishing the SBSN contract structure. The characteristics of the use of asset-based Sukuk inherent in the SBSN wherein the SBSN issuance that is transferred is not physical from assets the underlying, but the benefits of the 

the right to physical assets, and in the event of a default on SBSN, investors cannot own and sell these assets (Putri, Djuwityastuti, \& Sulistyono, 2015). Hanaf also said that related to the fulfillment of assets, ijaroh contract, which in this case uses the structure Sukuk-based asset, shariah compliance to the Sukuk Negara is still questionable (Hanaf, 2017).

Sovereign Sukuk also has the risk of non-compliance with sharia regulations (DJPPR, 2015). The risk of non-compliance with sharia regulations was also conveyed by Muhammad Jarkasih that there is one risk from the existence of Sukuk, namely the risk of non-compliance with sharia with the increasing structure of the development of Sovereign Sukuk (Zarkasih, 2011). Muchlis also conveyed the possibility of non-compliance with sharia regulations on Sukuk, thus suggesting the need for a review of the DSN fatwa regarding sharia bonds, in this case, focused on compliance with the DSN fatwa (Muchlis, 2015).

Some other facts related to the embodiment of Islamic accountability for the Sovereign Sukuk, Diyanti said that the allocation of expenditure originating from the Sovereign Sukuk issuance fund was not explicitly accounted for as a form of accountability so that people had difficulty in obtaining information on the use of these funds and this was not following what was directed in Islamic economics (Diyanti, 2010). In terms of the accounting practices of Sovereign Sukuk transactions, Zakia said that accounting practices for Sovereign Sukuk transactions are still equated with Government Securities (SUN) transactions (Zakia, 2014). It is due to the absence of specific standards governing the accounting for Sovereign Sukuk transactions while the standard for transactions is needed in order to provide investors confidence in the realization of sharia accountability (Edil \& Muhamad, 2008). With the existence of standards, the presentation and disclosure of Sovereign Sukuk transactions will be more accountable and following the needs of the community.

Various studies have been carried out in analyzing Sukuk and accountability. Alaudin et al. (2015) have studied the accountability of shariah transactions in Bank Syariah, and shariah training was a factor in achieving it. Abdirahman (2016) has also studied shariah accountability in Sukuk that results in different asset-based and asset-backed Sukuk. He also said shariah accountability must meet two criteria, that is form and substance. Grassa and Miniaoui (2017) has also studied about sukuk that result evidence the firm 
IQTISHADIA prefer issue sukuk rather than conventional bonds in the issuance of largee $13,1 \quad$ debt and $\log$ tenor.

This research gives perspective differently. Based on these conditions, the author will analyze factors that can increase Islamic accountability for the Sovereign Sukuk/SBSN. Several factors can support the realization of sharia accountability which include factors in the function of supervision (Nurhisam, 2016) and (Ahmed and Islam, 2019), human recourses competencies (Murtuza, 2002), leadership commitment (Ulah, 2014), decision-making authority (Ulah, 2014), and transparency on information (Hasan, 2013). Therefore, the authors will analyze the factors that have the highest level of importance in realizing sharia accountability for Sovereign Sukuk. Also, the writer will analyze the parameters/criteria that have the highest level of importance to be fulfilled so that sharia accountability for Sovereign Sukuk can be achieved. This research also gives benefits in the form of information to SBSN managers, Directorate of Sharia Financing-DJPPR, in increasing sharia accountability for SBSN, which will have an increasingly high impact on the level of trust and interest of the public to invest in the Sukuk Negara.

\section{LITERATURE REVIEW}

Sukuk in the National Sharia Council Fatwa (DSN) No. 69/DSN-MUI/ VI/2008) concerning State Sharia Securities, are state securities issued based on sharia principles, as proof of ownership of part of the assets SBSN, both in rupiah and foreign currencies. The definition is sharia accountability is an embodiment of the process of actualizing the implementation of sharia values by an entity that gives mercy to humans and nature as a form of servitude to God (Triyuwono, 2010). Sharia values, in this case, are compliance with sharia principles in every business transaction that complies with the prohibition of maysir, ghoror, and riba/usury. Islamic accountability has four parameters that must be applied with the aim of avoiding material mistakes that will reduce the legitimacy and trust of the community of sharia values inherent in sharia instruments/products (Rosly, 2010). The four parameters include the parameters of the contract, maqashid sharia, accounting, and financial reporting, and legal documentation (Rosly, 2010).

Factors for the realization of sharia accountability include supervisory factors, human resources competencies, leadership commitment, decisionmaking authority, and whether the factor of transparency of information. Haniffa conveyed the oversight function through the role of the National Sharia Council-Indonesian Ulema Council (DSN MUI) and the Sharia Supervisory Board (DPS) having a significant position in ensuring the implementation 
of sharia accountability in the determination of sharia products, operational activities and the resulting reporting (Haniffa, 2010). Idat in Nuronia also said that the oversight and inspection functions through the role of auditors, DPS, Bank Indonesia, OJK, and the community are needed in realizing effective sharia accountability Idat in (Nuronial, 2013). Murtuza Alaudin et al. and antics also said that the increased understanding and competence regarding scientific about sharia should be owned by the top management and the staff at the bottom so that the implementation of the accountability of sharia can be realized (Murtuza, 2002); (Alaudin, 2013); (Tantrum, 2014).

Commitment to leadership and decision-making authority according to Ulah (2014) is also essential in providing efforts that can realize sharia accountability, such as the leadership's commitment in providing programs to increase employee insight in the scope of sharia and the role of decisionmaking authority in setting regulations to comply with sharia principles, the stipulation of sharia guidelines and standards so that more $\mathrm{h}$ specific so that sharia accountability is more easily applied (Ulah, 2014). Huda (2013) also conveyed that accountability in the management of zakat is influenced by the commitment and leadership / institutional factors (Huda \& Sawarjiwono, 2013).

Other findings regarding factors that can realize sharia accountability are transparency of information. Weak transparency of information on financial statements provided by Islamic entities gives rise to a negative perception that the practices implemented by Islamic Financial Institutions are no different from conventional practices. The community still experiences difficulties in differentiating between sharia practices and conventional practices (Hasan, 2013).

The previous research about accountability and Sukuk has been carried out. Alaudin et al. (2013) have studied the accountability of shariah transactions in Bank Syariah, and shariah training was a factor in achieving it. Abdirahman (2016) has also studied shariah accountability in Sukuk that results in different asset-based and asset-backed Sukuk. He also said shariah accountability must meet two criteria, that is form and substance. Athur Murtaza (2002) found an Islamic accountability perspective in general financial. Hafji Ula (2014) have research about shariah compliance in Shariah Bank and result in supporting factors to realize accountability, that is the function of oversight of HR competencies in sharia, leadership commitment, and decision-making authorization. Muhammad Zarkasih (2011) about the factor commitment and competency affects shariah accountability. 
IQTISHADIA

13,1

\begin{tabular}{cl}
\hline Scale & Definition of "importance." \\
\hline 1 & Between criteria/sub-criteria one with the other is equally important \\
\hline 3 & $\begin{array}{l}\text { One criterion/sub-criteria is slightly more critical than other criteria/ } \\
\text { sub-criteria (moderate importance) }\end{array}$ \\
\hline 5 & $\begin{array}{l}\text { One criterion/sub-criteria is more critical than other criteria/ sub- } \\
\text { criteria (essential/strong importance) }\end{array}$ \\
\hline
\end{tabular}

Types of data used in this study, namely primary data and secondary data. Primary data is taken from interviews and questionnaires from key informants who are experienced and involved in the management of the Sovereign Sukuk. Informants selected in this study are those who have experience in managing SBSN, namely officials in the DJPPR agency, especially in the Directorate of Sharia Financing (DPS) and the Directorate of Evaluation, Accounting, and Settlement-DJPPR, as well as those who have interests and have mastery of knowledge in the sharia field, namely the Inspectorate General as the internal auditor of the DJPPR unit, the manager of the underlying assets (DJKN), DSN-MUI, and Sovereign Sukuk sales agents, in this case, Islamic Banks. The sharia banks selected as critical informants are BNI Syariah, Muamalat Bank, BRI Syariah, and Mandiri Syariah Bank. Secondary data is supporting data collected related to research, namely central government financial reports, asset reports that are used as underlying, and data regarding the development of issuance and the amount of outstanding Sovereign Sukuk.

The analysis method used in this study is the method of analyzing data in the form of numbers in the form of the assessment of the importance of each level of the ahp hierarchy from key informants through questionnaire results using the method Analytical Hierarchy Process (AHP). Methode AHP method, according to Thomas L. Saaty, is a perfect method used for this type of research with several variables, attributes, or qualitative research criteria. The AHP method is also mathematically based. The AHP method is a tool for determining choices from various difficult alternatives. In AHP, there is a hierarchical structure, consisting of several levels, the highest level, which is the desired goal, then the level of criteria to support the achievement of objectives, and after that, the level of sub-criteria to support the criteria (Saaty, 1990). These criteria are then compared using the AHP scale table to be seen in Table 1.

\section{Table 1. Scale of AHP}




\begin{tabular}{cl}
\hline 7 & $\begin{array}{l}\text { One criterion/sub-criteria is very strong important than other criteria/ } \\
\text { sub-criteria (extreme importance) }\end{array}$ \\
\hline 9 & $\begin{array}{l}\text { One criterion/sub-criteria is more important than other criteria/sub- } \\
\text { criteria (extreme importance) }\end{array}$ \\
\hline
\end{tabular}

2,4,6,8 This scale shows the rating among the values $1,3,5,7,9$

Based on the AHP method, in this research, consisting of several levels, the highest level (goal) is the shariah accountability Sovereign Sukuk, then the level of criteria to support the achievement of objectives, consist of structural contract SBSN, the use of SBSN funds by maqashid sharia, and SBSN accounting and financial reporting, and after that the level of sub-criteria (factors) to support the criteria. The results of the assessment conducted by each informant will be processed with the help of the program excel in obtaining the following:

1. The results of the assessment of sharia accountability criteria for the use of the contract structure, the use of funds, and accounting for SBSN transactions. The evaluation of each informant will be processed to obtain consistent index results as well as what criteria have the highest level of importance compared to other criteria. If the consistent results index $\leq$ 0.1, the assessment results will be taken into account in finding the highest average importance of criteria for all respondents. The composition of the evaluation of the criteria can be seen in Table 2 .

Table 2. Sample Pairwise Comparison Matrix

\begin{tabular}{lllc}
\hline & $\mathrm{X} 1$ & $\mathrm{X} 2$ & $\mathrm{X} 3$ \\
\hline $\mathrm{X} 1$ & 1 & & \\
\hline $\mathrm{X} 2$ & & 1 & \\
\hline $\mathrm{X} 3$ & & & 1 \\
\hline
\end{tabular}

After that, further process is the determination of the highest percentage of interest results and the level of logical consistency. At this stage, the assessment results for each element at each AHP level will be processed. This stage aims to determine the ranking of the criteria with each other, sub-criteria with one another, and alternatives with one another. At the level of logical consistency, each group or assessment at each level will be determined whether the results of the assessment have the consistency of the assessment or not. 
IQTISHADIA

13,1

60

2. The results of the evaluation of each informant in determining the level of importance of each sub-criteria of sharia accountability will be processed and produce consistent indexes and sub-criteria which have a higher level of importance compared to other sub-criteria in each of the criteria for sharia accountability. If the index is consistent $\leq 0.1$, the assessment results will be taken into account in finding the average sub-criteria that have the highest level of importance compared to the other sub-criteria for all respondents.

3. The results of the evaluation of each informant in determining the level of importance of each of the supporting factors for the realization of sharia accountability criteria will be processed and produce a consistent index and which factors have a higher level of importance compared to other factors in realizing sharia accountability criteria. If the index is consistent $\leq 0.1$, the assessment results will be taken into account in finding the average factor that has the highest level of importance compared to other factors for all respondents.

\section{RESULTS AND DISCUSSION}

In this section of the discussion, the author will first explain the results of the AHP hierarchy compilation of Sharia Sovereign Sukuk accountability, which can be seen in figure 2.

Figure 2. The Results of Sharia Accountability Hierarchy Sovereign Sukuk

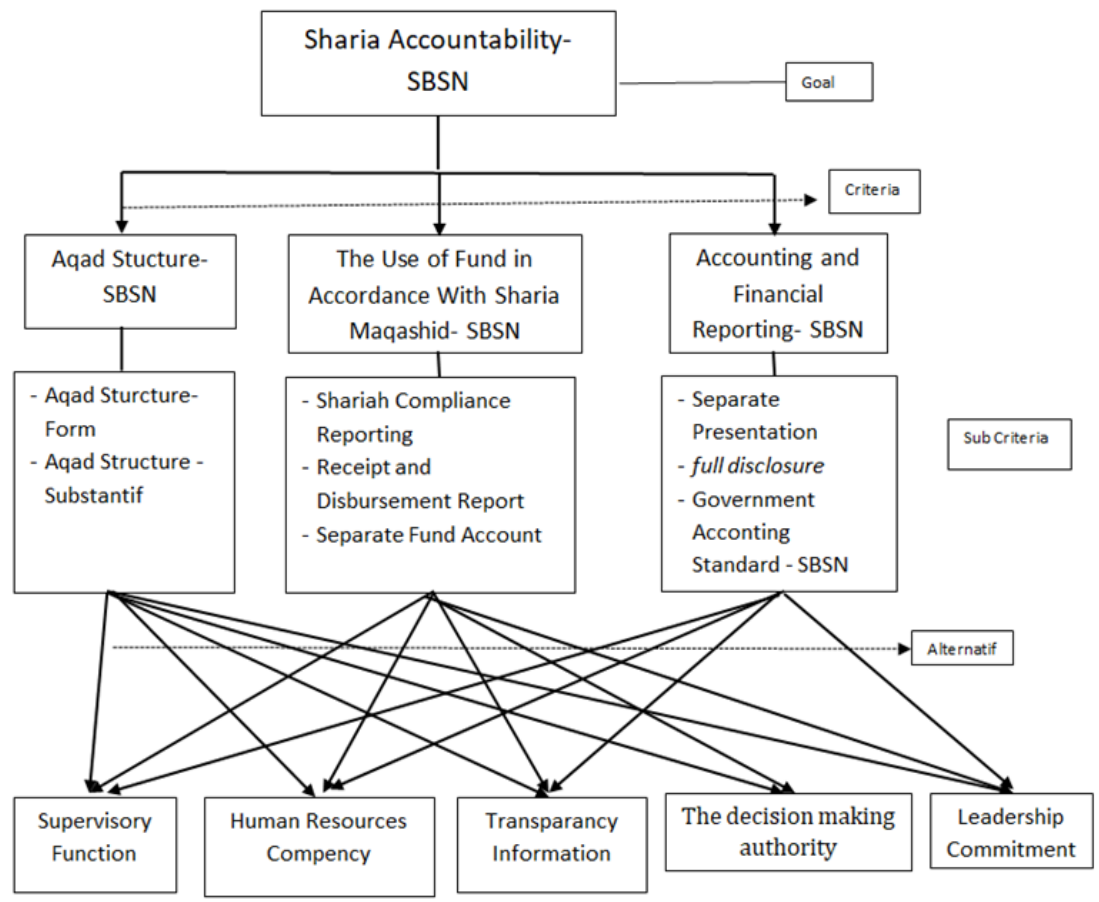


Compilation of preparation of this hierarchy will be used as a basis for critical informants to provide opinions or judgments in determining which criteria or sub-criteria or factors have a higher level of importance compared to the others. The hierarchy in the AHP method is organized into four levels with the highest / peak level or which is the aim of this study is Sharia Accountability for SBSN. Sharia accountability for SBSN shows Improve Sharia Accountability whether management related to SBSN has been implemented following sharia, in which case sharia accountability parameters will be seen, namely the use of the contract structure, the use of funds resulting from the issuance of SBSN, and accounting for SBSN transactions. These three parameters are based on Roesly's theory regarding the parameters of sharia accountability (Roesly). The three parameters of sharia accountability in this hierarchy are the criteria in realizing the goal/peak level, which is at the second level. At the third level, the criteria will be divided into sub-criteria, which also describe the conditions that should be met in realizing the criteria of sharia accountability for SBSN. At the fourth level is an alternative level or, in this case, which factors will have an interest in realizing sharia accountability for each sharia accountability parameter/criteria.

Based on the results of the questionnaire distributed to respondents totaling ten respondents, the next process of these results is processed using the Analytical Hierarchy Process Process. The following paragraphs will explain the results of the assessment of the importance of the Sovereign Sukuk accountability criteria and the supporting factors for each of these criteria.

The results of the informant's evaluation of the importance level of the Sharia accountability parameter for SBSN can be seen in table 3 .

Table 3. Results of the Importance level of Sharia Accountability Criteria for SBSN

\begin{tabular}{clccccc}
\hline & & \multicolumn{2}{c}{ Weight of Importance Criteria } & & \\
\cline { 3 - 5 } No. & $\begin{array}{l}\text { Key } \\
\text { Informant }\end{array}$ & $\begin{array}{c}\text { Contract } \\
\text { Structures }\end{array}$ & $\begin{array}{c}\text { Using } \\
\text { SBSN } \\
\text { Funds }\end{array}$ & $\begin{array}{c}\text { Accounting } \\
\text { for SBSN }\end{array}$ & $\begin{array}{c}\text { Consistency } \\
\text { Index }\end{array}$ & $\begin{array}{c}\text { Consistency } \\
\text { Ratio }\end{array}$ \\
\hline 1. & R. 1 & 0.5488 & 0.2411 & 0.2101 & 0.0077 & 0.0148 \\
\hline 2. & R. 2 & 0.1936 & 0.7254 & 0.0810 & 0.0273 & 0.0525 \\
\hline 3. & R. 3 & 0.1933 & 0.7242 & 0.0825 & 0.0273 & 0.0525 \\
\hline 4. & R. 4 & 0.1936 & 0.7254 & 0.0810 & 0.0273 & 0.0525 \\
\hline 5. & R. 5 & 0.6528 & 0.2241 & 0.1232 & 0.00028 & 0.00054 \\
\hline 6. & R. 6 & 0.4431 & 0.3875 & 0.1694 & 0.0077 & 0.0148 \\
\hline 7. & R. 7 & 0.7988 & 0.1864 & 0.2101 & 0.0137 & 0.0263 \\
\hline 8. & R. 8 & 0.5488 & 0.2411 & 0.2101 & 0.0077 & 0.0148 \\
\hline
\end{tabular}




\begin{tabular}{ccccccc}
\hline 9. & R. 9 & 0.634 & 0.106 & 0.26 & 0.0166 & 0.0319 \\
\hline 10. & R. 10 & 0.6560 & 0.1579 & 0.1862 & 0.0242 & 0.0243 \\
\hline Number & 4.7628 & 3.6191 & 1.6136 & & \\
\hline Average & 0.48 & 0.36 & 0.16 & & \\
\hline
\end{tabular}

Based on data from respondents' assessment results, the results obtained index consistency and ratios below or equal with 0.1. It shows that the evaluation of each informant for each criterion produces consistent answers so that it can be taken into account in finding the average level of importance of each criterion in realizing sharia accountability.

The results of the average informant's evaluation of the level of importance of sharia accountability criteria, sharia accountability criteria are produced in the use of SBSN contract structure it has the highest importance compared to other criteria, which in this case produces $48 \%$ more important than the criteria for the use of sharia-compliant funds (36\%) and sharia SBSN accounting (16\%). The following figure shows the importance of each of these criteria.

Figure 2. The Results of the Importance Level of Sharia Accountability Criteria

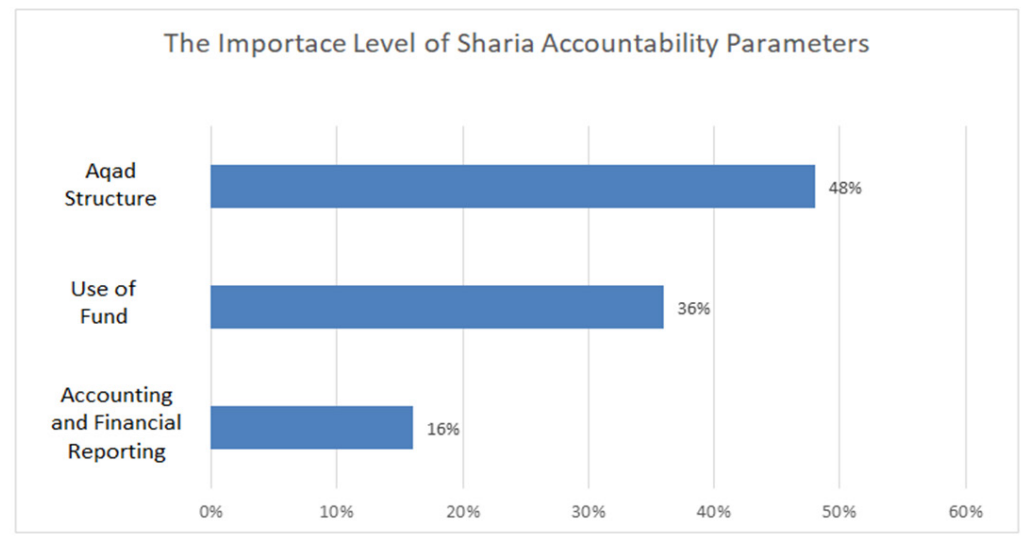

Results show that the criteria for using the contract structure are critical to apply, both in the fulfillment of documentation and in substance must be following sharia. This contract structure is the main differentiator between SBSN and SUN and several other types of state loans. Therefore, in determining the SBSN contract, DSN-MUI has the role of supervising and providing sharia compliance opinion on the issuance of SBSN.

As stated in the previous chapter, sharia accountability for the use of the SBSN contract structure still needs improvement. It can be seen that the determination of the SBSN contract structure still uses the principle asset- 
based Sukuk, where many opinions question the level of sharia compliance with the use of this principle. This is due to the compliance of sharia only limited to the fulfillment of documentation. At the same time, in substance, for example, in the determination of rewards not inline with the flow of assets Improve Sharia Accountability that are used as underlying assets, assets that are used as underlying assets non-physical assets so that investors cannot claim physical assets in the event of default repayment. The use of the principle of asset-based Sukuk provides information to the public that sharia compliance with SBSN has not been fully implemented.

In addition to the use of this principle, some conditions indicate that sharia accountability for the use of the contract structure is not optimal, including:

a. There is no easy access to data/information regarding the underlying assets of SBSN. It shows that there is one aspect of accountability, namely the report on underlying data assets and user(the highest level of accountability) (community/investor) has not been fulfilled. So far, the level of accountability reaches the organizational level. Reporting related to Sukuk transactions and the underlying elements such as underlying assets is addressed to the finance minister and has been approved by the Parliament. Besides every transaction related to SBSN, the manager always consults and reports to DSN-MUI.

b. Opinions from several respondents related to the implementation of SBSN management starting from the issuance, the use of funds, supervision of the underlying physical assets to the recording, and reporting remain consistent with the agreed Aqad structure. So, in this case, not only at the time of issuance is the first time to get shariah compliance opinion, but the implementation up to reporting also gets sharia compliance monitoring. It is deemed necessary to form a team that oversees the SBSN management activities, and there is a shariah compliance opinion on the implementation and reporting of SBSN transactions (results of an interview with a unit within the Ministry of Finance, 2017). Thus the accountability of sharia compliance in the implementation of the contract structure becomes clearer and increases the level of trust of the community (the highest level of accountability, i.e., the community level).

Based on these conditions, sharia accountability on the establishment of the SBSN contract structure is a top priority for improvement because these criteria are the highest contributors (48\%) in realizing sharia accountability for SBSN in general. 
IQTISHADIA

13,1

64

The following criteria that have a second level of importance after the criteria for using the contract structure, namely the criteria for using SBSN funds. Criteria for the use of SBSN funds have a higher level of importance compared to sharia accounting criteria for SBSN transactions, which is $36 \%$ in realizing sharia accountability. Sharia accountability criteria for the use of SBSN funds will be realized if the sub-criteria have been met, namely all aspects of accountability are met, and the supervision and accountability of the use of SBSN funds have been realized that can be known by the public/ investors. The use of SBSN funds following the MUI DSN fatwa must be following sharia objectives and can be accounted for in an accountable and transparent manner. The MUI DSN fatwa stipulates that the use of SBSN issuance results must not conflict with sharia principles.

As we know, the use of SBSN funds is used to cover the state budget deficit and as a source of funds to accelerate national development. It shows that the use of SBSN funds is beneficial for the development of the nation and state so that their use is not contrary to Islamic principles. Specifically for the SBSN which has structure Project-Based Sukuk (PBS)in which its use is to finance development projects such as the construction of roads, bridges, buildings, all of which in order to support the acceleration of national development, makes accountability very clear (Suminto in KLC video, 2017).

However, related to accountability for the use of SBSN issuance funds, some respondents provide advice and input on the use of SBSN funds allocated for general financing with a higher percentage of project financing, Shariah compliance accountability still needs improvement, that is, there is no detailed data report yet on the use of these funds. Expenditures for this financing can not be traced directly to what are the types of expenditures because it is feared that these funds are earmarked for interest expenses and other expenses which are prohibited in sharia principles. Besides, several respondents also informed that it was still difficult to access information on reports on the use of funds from the issuance of the SBSN so that accountability in this case still needed improvement in achieving the highest level of accountability, namely meeting the needs of the community/investors.

Sharia accountability criteria that have the lowest level of importance compared to other criteria in realizing sharia accountability are sharia accountability criteria related to sharia accounting for SBSN transactions, which reached $16 \%$. These criteria include the presentation, disclosure of SBSN transactions in Government Financial Statements, and the establishment of government accounting standards for sharia transactions. The purpose of this 

loans. With the existence of clear standards, presentation and disclosure can provide the information needed for the public/investors.

So far, the standard for recording SBSN transactions still refers to Government Accounting Standards so that there are no specific standards to be used as guidelines in accounting for SBSN transactions such as Corporate Sukuk, which already has a specific standard, namely PSAK number 110 on Sukuk accounting adjusted to sharia regulations. However, in this case, transactions related to SBSN already have a separate account code. SBSN transactions for their accounts are not combined with government bonds. The account for the issuance of SBSN, the account used is the SBSN account, for the benefits given to investors, the account used is not interest expense but SBSN rewards account.

However, related to the recording and reporting, there are still things that need to be improved; for example, related to the amortization account, there is a premium, and the SBSN issuance discount still uses an interest expense account. Besides that, in the financial reports for the work unit, there was still no SBSN group as well as LKPP, so the public could not access the information in the financial statements. It will affect the accountability of sharia SBSN transaction reports.

By looking at the level of importance of each criterion, we can see that each criterion does not have a significant difference in determining the realization of SBSN sharia accountability. Although the criteria for using the contract structure have a higher level of importance than the other criteria, the percentage is not more than $50 \%$. It shows that these criteria are not dominant in influencing the realization of Islamic accountability. All three criteria have an equally important position; it is just that at the moment, everything requires a process, and some criteria must be prioritized its refinement, such as the criteria for using the contract structure and management of SBSN funds that must be following sharia. It is consistent with the research conducted by Rosli (2010), who found that the four parameters of sharia accountability must be applied simultaneously and have complementary roles (Rosly, 2010).

The results of the assessment of factors with the highest level of importance for each criterion/ parameter of sharia accountability will be different. The following results of the assessment of the level of importance of the factors that affect the criteria for the contract structure can be seen in table 4 . 
IQTISHADIA

13,1
Table 4. The Results of Supporting Factors Assessment of the Aqad Structure Parameter

\begin{tabular}{|c|c|c|c|c|c|c|c|c|c|c|c|}
\hline & $\mathrm{R} 1$ & $\mathrm{R} 2$ & $\mathrm{R} 3$ & R4 & $\mathrm{R} 5$ & R6 & R7 & $\mathrm{R} 8$ & R9 & R10 & Average \\
\hline Competency & 0,27 & 0,076 & 0,44 & 0,49 & 0,44 & 0,06 & 0,2 & 0,49 & 0,44 & 0,49 & 0,35 \\
\hline Commitment & 0,04 & 0,166 & 0,05 & 0,06 & 0,21 & 0,17 & 0,2 & 0,06 & 0,05 & 0,06 & 0,11 \\
\hline Authority & 0,15 & 0,356 & 0,11 & 0,09 & 0,09 & 0,16 & 0,2 & 0,09 & 0,11 & 0,09 & 0,14 \\
\hline Transparancy & 0,09 & 0,068 & 0,11 & 0,09 & 0,09 & 0,10 & 0,2 & 0,09 & 0,11 & 0,09 & 0,11 \\
\hline Suervisory & 0,45 & 0,334 & 0,28 & 0,27 & 0,17 & 0,51 & 0,2 & 0,27 & 0,28 & 0,27 & 0,29 \\
\hline Total & $\mathbf{1 , 0 0}$ & 1,00 & 1,00 & 1,00 & $\mathbf{1 , 0 0}$ & $\mathbf{1 , 0 0}$ & $\mathbf{1 , 0 0}$ & $\mathbf{1}, \mathbf{0 0}$ & $\mathbf{1 , 0 0}$ & 1,00 & $\mathbf{1 , 0 0}$ \\
\hline Index Consistency & 0,21 & 0,09 & 0,09 & 0,04 & 0,02 & 0,05 & 0 & 0,04 & 0,09 & 0,04 & o,05 \\
\hline Index Random & 1,11 & 1,11 & 1,11 & 1,11 & 1,11 & 1,11 & 1,11 & 1,11 & 1,11 & 1,11 & 1,11 \\
\hline Ratio Consistency & 0,19 & 0,08 & 0,09 & 0,03 & 0,02 & 0,05 & o & 0,03 & 0,09 & 0,03 & 0,05 \\
\hline
\end{tabular}

Table 4 shows the results of the assessment of factors that have different levels of importance in realizing accountability sharia for the use of the SBSN contract structure. These results are processed through data from comparative data in pairs of respondents, which are then processed by using the Excel program to find the average value, index consistency (CI), and ratio consistency (CR). Random Index (RI) should be determined first if we want to calculate CI value. In this case, for five factors that affect each criterion, 1.11 is generated (see the Saaty table in the literature review chapter on the random index). With known CI and RI values, the ratio of consistency is calculated. If the consistency ratio is less than or equal to 0.1, the calculation can be accepted, which can then be calculated in finding the average percentage of importance.

Based on table 4, it can be seen that from 10 respondents, there is one respondent with the results of the calculation of the ratio consistency above o.1. The calculation result for respondent 1 is the index consistency value of 0.21 , while the ratio consistency of 0.19 . This value cannot be calculated in finding the average value of the importance of each factor in realizing sharia accountability criteria for the use of the SBSN contract structure. 
The results of these data can be seen that the HR competency factor has a higher level of importance (35\%) compared to other factors in realizing sharia accountability using the SBSN contract structure although the percentage results are not too dominant or not above 50\%, but higher than other factors. The second factor is the supervisory function with an interest rate of $29 \%$ followed by the third factor is the decision making authority (14\%), the fourth and fifth factors, namely the leadership commitment and transparency each have an interest rate of $11 \%$ in realizing sharia accountability using the SBSN contract structure.

A comparison of the level of importance of each factor can be seen in Figure 3 below.

Figure 3. The Results of Supporting Factors Assessment of the Aqad Structure Parameter

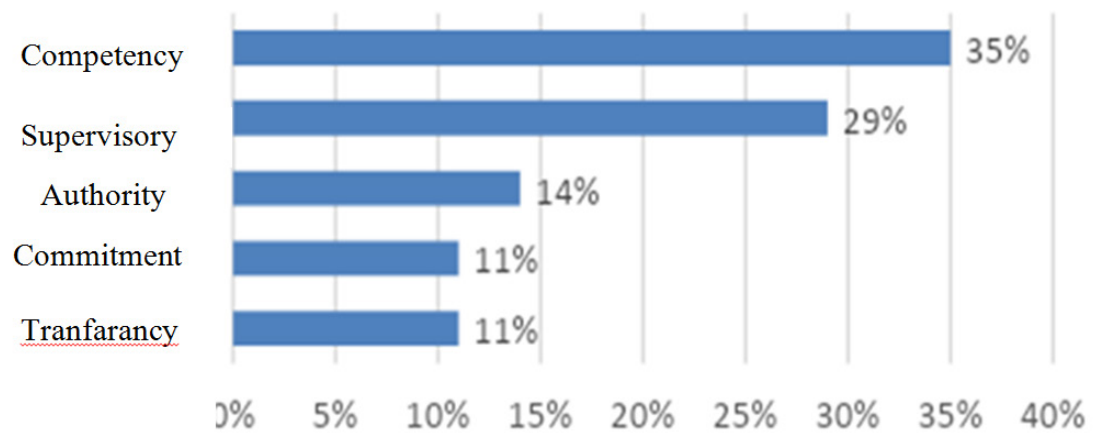

Human resources competency factors need to be explicitly developed related to knowledge and skills in the sharia field. With a deep understanding of the structure of the contract that can be used in the issuance of SBSN and the elements that must be fulfilled, such as the fulfillment of sharia on the required documents, parties related to the issuance, and fulfillment of sharia over its substance, sharia accountability for SBSN can materialize, specifically related to establishing the SBSN contract structure.

Competencies in the sharia field must be owned by SBSN managers both directly and indirectly, involved that can be obtained through training or non-training, such as comparative studies, participating in socialization, upgrading insights, seminars, and so on to increase the competency of employees in the sharia field. It aims to understand better and deepen the structure of Aqad and the elements associated with the structure of Aqad in Sovereign Sukuk transactions. 

by employees in the DGT-Directorate of Sharia Financing, DGT-Directorate of Evaluation and Settlement but must also be possessed by employees in the Inspectorate General as internal auditors, the Directorate General of State Assets correctly handling assets used as assets underlying assets, employees outside the Ministry of Finance, such as Sovereign Sukuk issuance agents (BRI Syariah Bank, MandiriSyariah Bank, Muamalat Bank), bidders (BNI Syariah).

The oversight function also has a high level of importance in realizing sharia accountability. The resulting percentage is $29 \%$, not much different from HR competence (35\%). Supervision of the SBSN that will be issued must be carried out so that sharia accountability can be maintained. The practice that has been related to supervision has been running, sharia accountability related to the establishment of the SBSN contract structure that has been issued has been implemented. The supervisory role is carried out by DSN MUI, who oversees the structure of the contract and document agreement between the investor, the SBSN issuer, and SPV contains an element of justice and ensures that the assets used as underlying assets meet all sharia aspects.

The following criteria for sharia accountability are the use of SBSN funds. As explained in the previous paragraph that the criteria for sharia accountability-the use of SBSN funds has a sub-criteria that are also current conditions that require improvement, namely there are no reports of receipt and disbursement of SBSN funds that can be traced and accessed by the public/investors, there is no supervision from the MUI DSN that provides an opinion report whether or not the use of SBSN funds is by sharia principles. There is no distinct account separation for SBSN funds. By looking at these conditions, this shows that the accountability of sharia has not been realized because several aspects have not been met, namely aspects of the report and aspects of the relationship between the issuers of SBSN have not provided information transparently to investors. Besides, when viewed from the level of accountability related to this achievement, the level of accountability has not reached the last level, namely the fulfillment of community interests.

Supporting factors will be determined based on the results of the respondents' assessment. These results indicate that one factor has a higher/ lower level of importance compared to other factors. The results of the assessment can be seen in Table 5 below . 
Table 5. Results of Assessment of Supporting Factors for Sharia Accountability in the Use of Funds

\begin{tabular}{|c|c|c|c|c|c|c|c|c|c|c|c|}
\hline & $\mathrm{R}-1$ & $\mathrm{R}-2$ & $\mathrm{R}-3$ & $\mathrm{R}-4$ & $\mathrm{R}-5$ & $\mathrm{R}-6$ & $\mathrm{R}-7$ & $\mathrm{R}-8$ & $\mathrm{R}-9$ & R10 & Average \\
\hline Competency & 0,23 & 0,04 & 0,13 & 0,06 & 0,07 & 0,06 & 0,2 & 0,16 & 0,13 & 0,16 & 0,14 \\
\hline Commitment & 0,11 & 0,13 & 0,06 & 0,16 & 0,38 & 0,17 & 0,2 & 0,16 & 0,06 & 0,16 & 0,16 \\
\hline Authority & 0,1 & 0,23 & 0,06 & 0,16 & 0,21 & 0,17 & 0,2 & 0,44 & 0,06 & 0,44 & 0,21 \\
\hline Transparancy & 0,42 & 0,07 & 0,23 & 0,30 & 0,12 & 0,10 & 0,2 & 0,06 & 0,23 & 0,06 & 0,19 \\
\hline Supervisory & 0,14 & 0,54 & 0,51 & 0,30 & 0,21 & 0,50 & 0,2 & 0,16 & 0,51 & 0,16 & 0,30 \\
\hline Total & 1 & 1 & 1 & 1 & 1 & 1 & 1 & 1 & 1 & 1 & 1 \\
\hline Index Consistency & $-0,27$ & 0,11 & 0,08 & 0,01 & 0,01 & 0,07 & o & 0,01 & 0,058 & 0,01 & \\
\hline Ratio Consistency & $-0,24$ & 0,11 & 0,07 & 0,01 & 0,01 & 0,07 & o & 0,01 & 0,052 & 0,01 & \\
\hline
\end{tabular}

How to

Improve Sharia Accountability

Table 5 shows the results of respondents' evaluation of the importance of the factors that support the realization of sharia accountability for the use of SBSN funds. The results show that there is one respondent with an index consistency value and a ratio greater than 0.1 so that the respondent's assessment will be excluded from the calculation looking for an average level of importance of each factor. The results of the average of the nine respondents were obtained that the highest percentage value was 30\% for the supervisory factor. The decision making authority factor was 215 , the transparency factor was $19 \%$, the leadership commitment, and HR competencies were $16 \%$ and $14 \%$, respectively.

These results indicate that the supervisory function factor has a higher level of importance than other factors. However, these results are not dominant that this factor is more important than other factors because the results of the assessment of each factor are evenly distributed and do not have a large margin. The difference in the level of importance between the factors can also be seen in Figure 4 below.

Figure 4. Importance of Factors Influencing Sharia Accountability in Using SBSN Funds

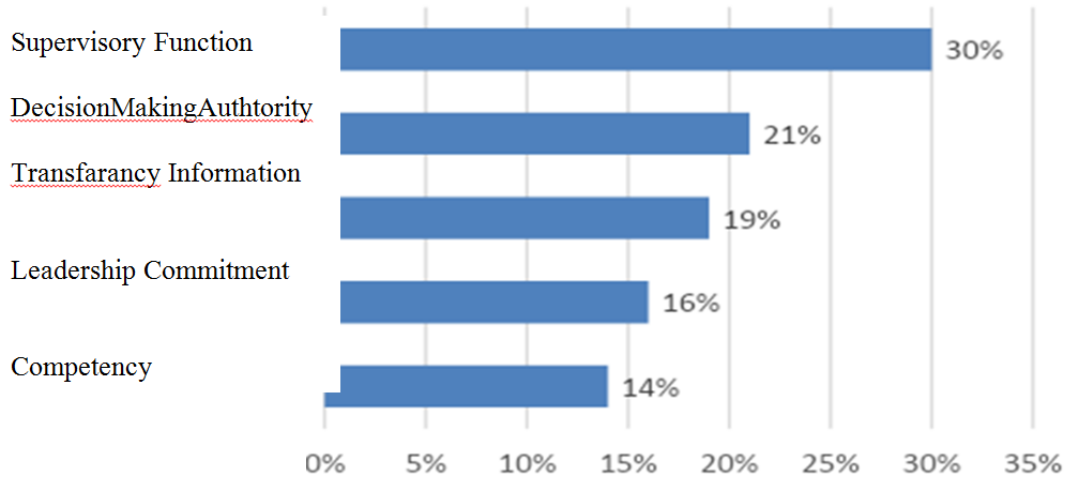


IQTISHADIA

13,1

70

The supervisory function has the highest yield (30\%) in realizing sharia accountability related to the use of SBSN funds. To realize compliance with sharia principles in the use of funds requires supervision that can be formed by a supervision team consisting of DSN MUI and other parties directly involved in managing the use of the SBSN funds. Internal auditors, Inspector General employees are also involved as members of the supervisory team using SBSN funds. The existence of this supervisory team aims to avoid the use that is not following sharia principles and to provide information to the public in the form of statements that have complied with sharia principles for the use of SBSN funds. It means that the oversight function of supervision before the issuance, use of funds, and the existence of reports that are following sharia principles will run effectively.

Based on the results, the calculation of the level of importance between the factors also produced the second factor in realizing sharia accountability for the use of Sukuk funds, authorization of decision-makers resulting in a percentage of $21 \%$. Based on the results of interviews with respondents, government authorization factors play an essential role in taking steps in realizing accountability in the use of funds following sharia. Besides, the role of the Financial Services Authority also plays an essential role in establishing the existence of regulations regarding the formation of a sharia compliance supervision team for the use of SBSN funds. These parties need to coordinate, which naturally requires the commitment of the leadership as the direct manager of the SBSN (DJPPR) with a yield of $16 \%$ to establish the necessary rules.

During this time, the proceeds of SBSN is used for general expenditures (general financing) is not visible accountability for the use of these funds. Reporting on the use of these funds has not been seen directly and is separate from the receipt of other sources (still one account). This is due to the results of the issuance of SBSN that are still united with the national treasury. Unlike the case with SBSN issued on a project basis or known as Project-Based Sukuk, the accountability for the use of funds resulting from the issuance of Sukuk is clear and transparent. The public can directly see the results of projects funded by the issuance of SBSN. Government authorities have an essential role in making policies and strategies related to this. Transparency factor becomes an important thing to implement. The policy of the leadership and decision-making authority, the supervisory function that must run to oversee the use of SBSN funds, are all expected to produce reports that can provide information to the public so that transparency, in this case, becomes an essential matter in achieving sharia accountability (19\%). 
Accountability is related to the application of sharia-compliant SBSN accounting, which has sub-criteria, namely the presentation of SBSN transactions in financial statements, disclosure of information related to SBSN, and the establishment of government accounting standards related to sharia transactions. The three sub-criteria have not been realized optimally until now. As stated in the previous chapters, the presentation and disclosure Improve Sharia Accountability of SBSN transactions are generated through an accounting cycle that has similarities with the SUN accounting process. Disclosure of SBSN at LKPP has not been able to provide complete information needed by the community, such as the type of contract, underlying asset data, and other information as disclosed in PSAK 110 that does not yet exist in LKPP.

However, there are several things related to SBSN accounting that already have differences with SUN accounting, related explicitly to account names. The SBSN transaction already has an account name and account code that is different from SUN and other state loans. For the benefits given to investors, do not use the interest expense account name, but have already used a different account name. It has just related to the amortization of premium/discount still using the name of the interest expense account. This amortization is carried out at the end of each year.

In order to realize sharia accountability for accounting for SBSN transactions, factors must be met. Table 6 is the result of the assessment of several respondents who showed which factors have a higher level of importance compared to other factors in realizing sharia accountability.

Table 6. Results of the Assessment of Supporting Factors Supporting Sharia-Accounting Accountability

\begin{tabular}{cccccccccccc}
\hline & R-1 & R-2 & R-3 & R-4 & R-5 & R-6 & R-7 & R-8 & R-9 & R10 & Avg \\
\hline Competency & 0,15 & 0,05 & 0,48 & 0,12 & 0,12 & 0,066 & 0,2 & 0,16 & 0,12 & 0,17 & 0,18 \\
\hline Commitment & 0,25 & 0,48 & 0,11 & 0,16 & 0,12 & 0,185 & 0,2 & 0,16 & 0,162 & 0,15 & 0,19 \\
\hline Authority & 0,46 & 0,25 & 0,11 & 0,42 & 0,48 & 0,185 & 0,2 & 0,44 & 0,421 & 0,44 & 0,32 \\
\hline Transparancy & 0,1 & 0,09 & 0,27 & 0,24 & 0,21 & 0,456 & 0,2 & 0,16 & 0,237 & 0,16 & 0,22 \\
\hline Authority & 0,04 & 0,13 & 0,04 & 0,06 & 0,07 & 0,108 & 0,2 & 0,06 & 0,061 & 0,06 & 0,09 \\
\hline Total & 1 & 1 & 1 & 1 & 1 & 1 & 1 & 1 & 1 & 1 & 1 \\
\hline Index Consistency & 0,54 & 0,023 & 0,07 & 0,4 & 0,01 & 0,01 & 0 & 0,01 & 0,079 & 0,01 & 0,03 \\
\hline Random Index & 0,49 & 0,021 & 0,06 & 0,4 & 0,01 & 0,01 & 0 & 0,01 & 0,071 & 0,01 & 0,02 \\
\hline
\end{tabular}

The results of the assessment based on table 6 contained two respondents ( $\mathrm{R}-1$ and $\mathrm{R}-4$ ) resulting in an index consistency and a ratio consistency greater than 0.1 so that the results of this assessment were excluded from 
IQTISHADIA

13,1

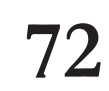

the calculation looking for an average level of importance. The average results show that factors that have a higher level of importance compared to other factors are factors of decision making authority with $32 \%$ results. Next is the transparency factor, leadership commitment, HR competence, and supervision with results of $22 \%, 18 \%, 19 \%$, and $9 \%$, respectively.

The most dominant factors in realizing sharia accountability produce different results in each of these parameters. For the accountability of sharia SBSN contract structure parameters, the most dominant factor is the competency that must be possessed by HR, especially competence in the sharia field. It is following previous research conducted by Murtuza, Alaudin, et al., and Utah, who stated that increasing understanding and competence regarding scholarship on sharia could realize sharia accountability (Murtuza, 2002); (Alaudin, 2013); (Acts, 2014).

For sharia accountability, parameters for the use of SBSN funds are following shariah principles, and the most dominant factor is the supervisory function. It is consistent with Nurhisam and Hanniffa's research (Haniffa, 2010), which conveys the supervisory function to realize sharia values. The last parameter is related to accounting and financial reporting. The most dominant factor in realizing this parameter is the decision making authority. It is following the study of Ulah, which states that decision-making authority is indispensable for providing efforts to establish regulations in compliance with sharia principles and the establishment of sharia guidelines and standards to be more specific so that sharia accountability is more easily applied (Ulah, 2014).

\section{CONCLUSION}

The highest importance level in realizing the sharia accountability for the use of the contract structure (aqad) SBSN parameter is human resources competency factors, for the use of SBSN funds by the shariahmaqashid is supervisory function factors, and for accounting and financial reporting parameters is decision-making authority factors. The criteria/parameter for the realization of sharia accountability for SBSN, which has the highest importance level, is the sharia accountability criteria for using the contract structure. The resulting level of importance is $48 \%$ in realizing SBSN sharia accountability.

The results of this study are beneficial for the managers of the Sovereign Sukuk/SBSN to improve sharia accountability by looking at the factors that have the highest level of importance. Based on the conclusions, 
the role of human resources is significant in mastering the understanding of sharia transactions, especially Sovereign Sukuk. Managers need to strive to develop the competencies of their human resources and also need to conduct socialization to the public continuously. The three parameters that are the object of research have an interrelated position where everything must be realized. It aims to increase the trust and interest of the community to invest Improve Sharia Accountability in the Sukuk Negara.

\section{LIMITATION}

The parameters used by researchers as sharia accountability criteria for SBSN are only the contract ( $a q a d$ ) structure, the use of the fund by sharia maqashid, and financial accounting and reporting. Legal document parameters cannot be carried out due to limitations given by SBSN managers because they are confidential on these documents. According to maqashid Syariah, this study did not analyze the basic needs of sharia maqashid; namely, the basic needs in Islamic law are a religion (Din), Life (Nafs), Family (Nasl), Intellect ('Aql) and Property $(\mathrm{Mal})$. It is due to time constraints, and it is expected that basic research needs from this basic maqashid will be carried out by subsequent researchers. The use of AHP by involving an expert by giving his opinion also has weaknesses because the answers given can be in the form of perception. It can give effect to the results of the AHP is inseparable from mistakes.

\section{REFERENCES}

Abdullah, A. (2012). Asset Based VS Asset Backed Sukuk. Islam and Civilisational Renewal ICR Jurnal. IAIS Malaysia, Volume 3(4).

Ahmed, E., Islam, M., \& Amran, A. (Mei 2019). Examining The Legitimacy of Sukuk Structure via Shariah Pronouncements. Journal of Islamic Marketing.

Alaudin, S., \& Addler. (2015). Beliefs and Accountability in Islamic Banks. Corporate Ownership and contro Jurnal, Vol 12, Issue 4.

Ayub, M. (2007). Understanding Islamic Finance. Ltd.London: John Wiley and Sonc.

Chapra, M., \& Ahmad, H. (2002). Corporate Governance in Islamic Financial Institutions. Jeddah: Islamic Development Bank. Islamic Research and Training Institute. 
IQTISHADIA

13,1

74

Direktorat Jenderal Pengelolaan Pembiayaan dan Risiko Kementerian Keuangan. (2018). Profil Utang dan Penjaminan Pemerintah Pusat. Jakarta: DJPPR, Kementerian Keuangan.

Diyanti. (2010). Tinjauan Ekonomi Islam Terhadap Alokasi Dana Sukuk dalam APBN. Fakultas Syariah dan Hukum. UIN Syarif Hidayatullah. Jakarta.

DSN - MUI. (2008). Fatwa Dewan Syariah Nasional Nomor 69/DSN-MUI/ VI/2008 tentang Surat Berharga Syariah Negara. Jakarta.

Edil, M., \& Muhammad, R. (2008). Malaysian Sukuk: Issues in Accounting Standard Introduction. Shariah Journal, Vol.16 No. 1, 63-74.

Fambudi, D.I. (2017). Tinjauan Hukuk Islam Terhadap Akad Ijarah Asset to Be Leased pada Produk Sukuk Negara Ritel SR-oo8 di Bank BTN Semarang. Fakultas Syariah dan Hukuk. UIN Walisongo. Semarang. Retrieved from http://eprints.walisongo.ac.id/7792/.

Grassa, R., \& Miniaoui, H. (2017). Corporate Choice between Conventional bond and Sukuk issuance Evidence from GCC countries. Qatar: Research in International Business and Finance.

Haniffa, R. (2010). Auditing Islamic FInancial Institutions, in Islamic Finance: Instruments and Markets. Bloomsburry, London. Q FInance. Article.

Herzi,A.A. (2016). AComparativeStudy ofAssetBased and Asset Backed Sukuk from The Shariah Compliance Perspective. JMFIR, 13(1), retrieved from http://ddms.usim.edu.my/jspui/handle/123456789/14445.

Hasan, H. (2013). Meningkatkan Transparansi dan Disiplin Pasar Perbankan Syariah di Indonesia. Economica: Jurnal Ekonomi Islam, 4(1), 125140.

Hidayat, N. (2004). Prinsip-Prinsip Akuntansi Syariah: Suatu ALternatif Menjaga Akuntabilitas Laporan Keuangan. Papaer presented at Simposium Nasional Akuntansi VII. Denpasar.

Huda, N., \& Sawarjuwono, T. (2013). Akuntabilitas Pengelolaan Zakat melalui Pendekatan Modifikasi Action Research. Jurnal Akuntansi Multiparadigma, 4(3), 376-388.

Idat, D. G. (2003). Trend Bank Syari'ah: Penurunan Terhadap Kepatuhan Prinsip Syari'ah. Media Akuntansi, Edisi, 33, 30-31.

Ikatan Akuntan Indonesia. (n.d.). PSAK Nomor 110 tentang Akuntansi Sukuk. . 
Jarkasih, M., \& Rusydiana, A. S. (2009). Perkembangan pasar sukuk: perbandingan Indonesia, Malaysia, dan dunia. The development of the sukuk market: the comparison of Indonesia, Malaysia, and the world], Jurnal Bisnis dan Ekonomi, 1(2), 1-18.

Labolo, M., \& Achyari, M. F. (2018). The Potential of Sukuk Issuance as an Alternative Financing Instrument in Aceh Province. KnE Social Sciences, 297-311.

Murtuza, A. (2002). Islamic Attecendents for Financial Accountability International Journal of Islamic Financial Service. Islamic Attecendents for Financial Accountability International Journal of Islamic FInancial Service, 4 (1): 1-19.

Nasrullah, A., Burhan, U., \& Multifiah, M. (2013). Studi Kepatuhan Syariah Dan Manfaat Ekonomi Terhadap Minat Investor Dalam Pembelian Sukuk Negara. La_Riba: Jurnal Ekonomi Islam, 7(1), 41-6o.

Nurhisam, L. 2016. Kepatuhan Syariah (Sharia Compliance) dalam Industri Keuangan Syariah. Jurnal Hukum IUS QUIA IUSTUM. Vol 23 (1): 7796.

Nuronia, K. (2013). Akuntabilitas BMT Perspektif Syariah: Studi Kasus di Baitul Maal Wa Tamwil (BMT) Maslahah Mursalah Lil Ummah (MMU). Pasuruan: UIN Maulana Malik Ibrahim, Malang.

Pusdiklat Keuangan Umum, BPPK. (2017). Utang untuk Percepatan Pembangunan Nasional. Buku Seri Evolusi Unit Eselon I DJPPR. Jakarta: Pusdiklat Keuangan Umum.

Putri, A. M., Djuwityastuti, D., \& Sulistyono, A. (2016). Implementasi Penerbitan Surat Berharga Syariah Negara Seri Sukuk Negara Ritel Berdasarkan Undang-Undang Nomor 19 Tahun 2008 Tentang Surat Berharga Syariah Negara. Privat Law, 3(2), 163565.

Rizali, M. (2010). Konstruksi Hukum Sukuk Berdasarkan Fiqih Muamalah. Tesis. Fakultas Hukuk. Universitas Islam Indonesia. Yogyakarta. Retrieved from https://dspace.uii.ac.id/handle/123456789/8993.

Rosly. (2010). Shariah Parameters Reconsidered. International Journal of Islamic and Middle Eastern Finance and Management, 3 (2) : 37-47.

Saaty, T. (1990). The Analytical Hierarchy Process in Conflict Management. . International Journal of Conflict Management., 1 (1): 47-68.

Sivalingam, G. (2013). The Islamic Bond Market in Malaysia. In Regional Outlook. Asian \& Europian Business Collection (p. 119).

Sukuk dan Aspek Kepatuhan Syariah. (2016). Retrieved from Republika. co.id. 
IQTISHADIA

13,1

76

Triyuwono, I. (2010). Perspektif, Metodologi, dan Teori Akuntansi Syariah. Jakarta: PT Raja Grafindo Persada.

Ulah, H. (2014). Shariáh Compliance in Islamic Banking. An Empirical Study on Selected Islamic Bank in Bangladesh. International Journal of Islamic and Middle Eastern Finance and Management. Macquarie University, 7(2): 182-199.

Yahya, M. (2015). Analisis Normatif Kritis Kebijakan Pemanfaatan Obligasi Syariah (Sukuk) dalam Menutupi Defisit APBN. Economica JurnalJurnal Ekonomi Islam, 6(2): 37-56.

Zakia, B. U. (2014). Analisis Perlakuan Akuntansi SBSN Berdasarkan PSAK 110 tentang Akuntansi Sukuk. Fakultas Ekonomi dan Bisnis. Universitas Indonesia Jakarta. 